\title{
PELATIHAN MICROSOFT OFFICE WORDBAGI SISWA DAN GURU SEKOH DASAR NEGERI 62 BENGKULU
}

\author{
Rika Erlinda*1, HeriBudiarto ${ }^{2}$, Hendri Alamsyah ${ }^{3}$ \\ Rekayasa SistemKomputer, Universitas Dehasen, Bengkulu \\ Email: *rikaerlinda@gmail.com
}

\begin{abstract}
ABSTRAK
Sesuai dengan judul program pengabdian masyarakat ini, metode penerapan ipteks yang dilakukan adalah berbentuk pelatihan pengenalan microsoft office word untuk siswa dan guru SD Negeri 62 kota Bengkulu. Kegiatan pelatihan keterampilan ditunjang dengan ceramah, tanya jawab dan tentu saja praktek secara langsung di ruangan kelas SD Negeri 62 kota bengkulu. Modulpelatihan akan diberikan kepada peserta sebagai alat bantu dalam kegiatan praktek. Tujuan dari pelaksanaan program pengabdian masyarakat ini adalah untuk meningkatkan keterampilan Microsoft Office word bagi siswa dan Guru SD Negeri 62 kota bengkulu. Dari hasil evaluasi serta temuan-temuan yang kami peroleh selama pelaksanaan kegiatan P2M ini, dapat kami simpulkan bahwa program P2M ini telah mampu memberikan manfaat yang sangat besar dan tepat sasaran bagi khalayak siswa dan guru peserta pelatihan yang menjadi khalayak sasaran dalam kegiatan ini. Bentuk pelatihan seperti ini merupakan bentuk yang sangat efektif untuk memberikan penyegaran dan tambahan wawasan serta pengetahuan baru di bidang teknologi informasi di luar proses pembelajaran yang diterima di sekolah .
\end{abstract}

Kata Kunci:Microsoft Office word, Guru SD Negeri 62 kota bengkulu

\section{PENDAHULUAN}

Di jaman modern seperti saat ini, teknologi menjadibagian penting dalam kehidupan sehari-hari, khususnya teknologi komputer. Adanya perkembangan dan kemajuan di bidang teknologi tersebut membuat pekerjaan manusia menjadi semakin mudah dan cepat untuk diselesaikan. Dengan adanya komputer, akan mempermudah manusia dalam melakukan pekerjaannya, sehingga komputer menjadi salah satu alat teknologi informasi yang berpotensi memberikan nilai praktis dan tepat guna bagi kehidupan manusia. Ilmu Komputer merupakan skill yang wajib dimiliki setiap orang, tak terkecuali bagi anak SD sekalipun. Karna dengan dilatihnya ilmu komputer sejak dini, bisa membuat sang anak akan semakin mahir untuk kedepannya. Dan SD Negeri 62 bengkulu, sebagai bentuk program kerja yang akan kami laksanakan dengan mengadakan Pelatihan Microsoft Word bagi siswa dan guru.Berdasarkan pada latar belakang masalah yang ada maka penyusunan proposal pengabdian masyarakat ini dilaksanakan untuk dapat mengetahui, memahami, mengoperasikan komputer, dapat membuka Microsoft word dan bisa menggunakannya. Setidaknya mereka sudah dapat melatih diri mereka untuk mengetik dan mengenal toolbar.

\section{METODE}

Untuk memecahkan masalah yang sudah diidentifikasi dan di rumuskan tersebut diatas, metode kegiatan pelaksanaan pengabdian ini berupa pelatihan dan sosialisasi yang dilakukan untuk siswa dan guru di SD Negeri 62 Bengkulu. Setelah diberikan pelatihan dan sosialisasi, siswa dan 

microsoft office word.Berikut ini adalah tahapan pelatihan dan sosialisasi yang dilakukan:

a. Tahapan Persiapan

Tahapan persiapan yang dilakukan meliputi

1. survey.

Pemantapan dan penentuan lokasi dan sasaran .

2. Penyusunan dan pembuatan bahan/materi pelatihan dan sosialisasi yaitu modul

b. Tahapan Pelaksanaan Pelatihan Guru

Tahapan pelaksanaan pelatihan dilakukan diantaranya :

1. Office Word.

Manfaat dan kegunaannya dari sisi guru dan siswa adalah membantu meningkatkan kualitas pembelajaran sekolah dasar.

c. Metode pelatihan Untuk melaksanakan kegiatan tersebut digunakan beberapa metode pelatihan yaitu :

1. Metode ceramah

Metode ini memberikan penjelasan mengenai materi pelatihan dan memotivasiguru-guru agar mampu dan memiliki kreatifitas dalam mengembangkan media pembelajaran.

2. Metode tanya jawab sangat penting dapat mengukur peserta pelatihan dapat menerima penjelasan dari materi yang diberikan.

3. Metode simulasi : metode simulasi ini diberikan kepada peserta pelatihan yaitu guru untuk memberikan kesempatan mempraktekan materi pelatihan yang diperoleh. Harapannya guru akan benar-benar menguasai materi pelatihan yang diterima.

d. Tahapan Sosialisasi ke Siswa Tahapan sosialisasi ke siswa dengan harapan siswa dapat mengoperasikan komputer dan menggunakan Microsoft Office Word serta meningkatkan kemandirian belajar siswa melalui pelatihan Microsoft Office Word.

\section{HASIL DAN PEMBAHASAN}

A. Evaluasi Keberhasilan

Keberhasilan pelaksanaan program pengabdian masyarakat ini dilihat dari dua kur sebagai berikut :

1. Respons positif dari peserta pelatihan Respons peserta pelatihan ak an di ukur melalui observasi selama pelatihan berlangsung dan dengan memberikan kuesioner yang menyangkut kesan, saran, kritik dan usulan peserta pelatihan terhadap program pengabdian masyarakat ini.

2. Meningkatnya keterampilan peserta setelah mendapat pelatihan Keterampilan peserta pelatihan akan diobservasi saat pelatihan melalui pemberian tugas-tugas contoh latihan selama pelatihan

B. Alasan Kelanjutan Kegiatan

Selama pelaksanaan program pelatihan ini, mulai dari tahap persiapan sampai pelaksanaannya, dapat kami sampaikan temuan-temuan sebagaiberikut :

1. Antusias peserta pelatihan sangat tinggi, menyambut dengan baik tawaran kerjasama sebagai mitra dalam program pengabdian masyarakat ini. Pihak sekolah berharap program ini bisa dilaksanakan secara regular dan berkala di tahun-tahun selanjutnya.

2. Materi pelatihan yang diberikan sangat sesuai dengan level pembelajaran untuk siswa dan guru SDN 62 Kota Bengkulu, terlihat dari efektifitas dan tingkat kesulitan pengenalan aplikasi baru yang tidak terlalu memberatkan bagi para peserta pelatihan. Materi ini benar-benar memberikan penyegaran dan penambahan wawasan atas programprogram aplikasi di luar yang telah mereka dapatkan di sekolah.

\section{KESIMPULAN DAN SARAN}

A. Kesimpulan

Dari hasil evaluasi serta temuan-temuan yang kami peroleh selama pelaksanaan kegiatan P2M ini, dapat kami simpulkan bahwa program P2M ini telah mampu memberikan manfaat 


\section{Urnal PADAMU NEGERI}

(Community Service in the Field of Science, Technology, and Agricultural)

Available online at : http://journal.pdmbengkulu.org/index.php/padamunegeri

DOI: DOI: https://doi.org/10.37638/PadamuNegeri.1.1.35-37

yang sangat besar dan tepat sasaran bagi khalayak bagi siswa dan guru SDN 62 Kota Bengkulu yang menjadi khalayak sasaran dalam kegiatan ini. Bentuk pelatihan seperti ini merupakan bentuk yang sangat efektif untuk memberikan penyegaran dan tambahan wawasan serta pengetahuan baru di bidang teknologi informasi di luar proses pembelajaran yang diterima di sekolah.

B. Saran

Sesuai dengan hasil evaluasi respons yang telah dilakukan, kami menyarankan hendaknya program-program pengabdian masyarakat seperti ini bisa dilaksanakan secara reguler dan berkala, melihat tingkat kebutuhan yang sangat tinggi akan pengenalan aplikasi-aplikasi komputer yang baru, dalam jangka waktu yang relatif singkat mengikuti perkembangan teknologi secara global.

\section{DAFTAR PUSTAKA}

Djamarah Syaiful Bahri, (2008). "Psikologi Belajar". Rineka Cipta: Jakarta

http://kknkepanjenjember.web.unej.ac.id/2015/01/09/pengenalan-dan-pelatihanmengoperasikankomputer-bagi-siswa-sd/

http://inidesakita.blogspot.co.id/2016/09/pelatihan-microsoft-word-bagi-para.html 